\title{
Terminal leptospirosis in a woolly monkey (Lagothrix lagothricha) in Colombia
}

\author{
Leptospirosis terminal en un mono lanudo \\ (Lagothrix lagothricha) en Colombia
}

\author{
Viviana González A, ${ }^{1 *}$ M.Sc, Juliana Peña $S,{ }^{2}$ MV, Javier Bustamante ${ },{ }^{1}$ M.Sc, \\ Miryam Astudillo $\mathrm{H}^{1}{ }^{1}$ M.Sc.
}

\begin{abstract}
${ }^{1}$ Universidad del Valle, Facultad de Salud, Grupo de Biotecnologia y Enfermedades Bacterianas, Av $1 \mathrm{~N}$ No. 3N-03, Cali, Colombia. ${ }^{2}$ Fundacion Zoologica de Cali, Carrera 2 Oeste Calle 14, Cali, Colombia. *Correspondencia: vivianarjbr@gmail.com
\end{abstract}

Recibido: March 2014; Aceptado: November 2014.

\begin{abstract}
A captive woolly monkey (Lagothrix lagothricha) displayed severe lethargy, vomiting and diarrhea. Laboratory tests revealed anemia, leukopenia, hypoproteinemia, severe azotemia and positive Leptospira IgM ELISA. The monkey was humanely euthanized and the necropsy revealed a multifocal tubulointerstitial glomerulonephritis; in addition to splenic lymphoid depletion, and interstitial pneumonia, all of which are compatible with leptospirosis. Rodent control and biosecurity measures should be done at all zoological collections in order to prevent transmission to facility personnel and to threatened mammals maintained in captivity.
\end{abstract}

Key words: Epidemiology, leptospira, primate, zoo (Source: DeCS).

\section{RESUMEN}

Se presenta el caso clínico de un mono lanudo (Lagothrix lagothricha) en cautiverio, con letargia, vómito y diarrea. Las pruebas de laboratorio revelaron anemia, leucopenia, hipoproteinemia, azotemia severa y ELISA IgM positiva a Leptospira. El mono fue humanamente sacrificado y la necropsia reveló una glomerunonefritis tubulointersticial multifocal; además de depleción linfoidea esplénica, y neumonía intersticial, los cuales son compatibles con leptospirosis. Todas las colecciones zoológicas deberían realizar protocolos de desratización y aplicar medidas de bioseguridad para prevenir la transmisión al personal y mamíferos amenazados mantenidos en cautiverio.

Palabras clave: Epidemiologia, leptospira, primate, zoológico (Fuente: DeCS). 


\section{INTRODUCTION}

Leptospirosis is the most widespread rat-borne zoonosis in tropical regions, also affecting mammals other than the maintenance host in tropical regions $(1,2)$, caused by pathogenic serovars of the spirochete Leptospira spp. Transmission occurs through direct or indirect routes with contaminated bodily fluids from domestic maintenance hosts such as Rattus spp. and Mus spp. (2). Fatalities typically arise due to renal-vascular dysfunction that leads to renal, cardiac, or respiratory failure (3). Naturally acquired infection with Leptospira is uncommon in non-human primates (4), with only scant reports of seroreactivity in wild primates (5) and asymptomatic seroconversion occurring in primates in zoos $(6,7)$. However, captivity-associated confinement of non-native species may increase exposure to peridomestic reservoirs, promoting pathogen transmission potential to animals and personnel (6). This report details a clinical case of leptospirosis in a captive woolly monkey (Lagothrix lagothricha).

\section{CASE REPORT}

A zoo-born, adult $8 \mathrm{~kg}$ male woolly monkey (Lagothrix lagotricha) had been part of the collection of the Zoological Foundation of Cali, Colombia, since 1997. The monkey was a dominant male that shared the enclosure with other members of the same species. In June 2010, the monkey was reported to be severely lethargic, vomiting and passing diarrhea. On day one, anesthesia was performed in order to conduct a physical examination, and to collect blood for a complete blood count, serum biochemistry, serology, and urine for a darkfield examination and urinalysis. Antibiotic and supportive treatment was also administered under anesthesia. The physical exam determined a good body condition (4/5), dehydration of $10 \%$, and lymphadenopathy of the submandibular, axillary, inguinal and popliteal lymph nodes.

The monkey had moderate anemia with unremarkable values of both mean corpuscular volume and mean corpuscular hemoglobin, indicating a normocytic normochromic anemia characterized by severe poikilocytosis and polychromasia, with many echinocytes, and moderate Howell-Jolly bodies, in addition to leukopenia with moderate neutropenia. Platelet count was within normal International Species Information System (ISIS) ranges and no bands were detected. Of interest, the biochemical panel revealed hypoalbuminemia and hypocalcemia. We also detected marked increment of alanine

\section{INTRODUCCIÓN}

La leptospirosis es la zoonosis transmitida por ratas más común en regiones tropicales, afectando también a los mamíferos distintos del reservorio en regiones tropicales $(1,2)$, y es causada por serotipos patógenos de la espiroqueta Leptospira spp. La transmisión se produce a través de rutas directas o indirectas con fluidos corporales contaminados de reservorios domésticos como Rattus spp. y Mus spp. (2). Las muertes ocurren típicamente debido a disfunciones renales vasculares que conlleva a insuficiencia renal, cardíaca o respiratoria (3). La infección adquirida naturalmente por Leptospira es infrecuente en primates no humanos (4), con tan sólo algunos escasos informes de seroreactividad en primates salvajes (5) y seroconversión asintomática en primates en zoológicos $(6,7)$. Sin embargo, el confinamiento asociado al cautiverio de especies no nativas puede aumentar la exposición a los reservorios peridomésticos, facilitando la transmisión potencial de patógenos para los animales y el personal (6). En este informe se detalla un caso clínico de leptospirosis en un mono lanudo en cautiverio (Lagothrix lagothricha).

\section{REPORTE DEL CASO}

Un mono lanudo (Lagothrix lagotricha) macho adulto, nacido en cautiverio de $8 \mathrm{~kg}$ que formaba parte de la colección de la Fundación Zoológica de Cali, Colombia, desde 1997. El mono era un macho dominante que compartía el recinto con otros miembros de la misma especie. En junio de 2010, se reportó que el mono sufría de letargo, vómito y diarrea severa. En el primer día, se le aplicó anestesia para llevar a cabo un examen físico y para recoger muestras de sangre para un examen de hemograma, bioquímica sérica, serología y orina. También se administró un tratamiento antibiótico y de apoyo bajo la anestesia. En el examen físico se determinó una buena condición corporal (4/5), deshidratación del $10 \%$ y linfadenopatía de los ganglios linfáticos submandibulares, axilares, inguinales y poplíteos.

El mono sufría de anemia moderada con valores comunes de volumen corpuscular medio y hemoglobina corpuscular media, indicando una anemia normocítica normocrómica caracterizada por poiquilocitosis y policromasia severa, con un gran número de equinocitos y cuerpos de HowellJolly moderados, además de leucopenia con neutropenia moderada. El conteo de plaquetas estuvo dentro de los rangos normales del Sistema Internacional de Información de Especies (ISIS) y no se detectó ninguna banda. El análisis bioquímico reveló hipoalbuminemia y hipocalcemia. También se detectó un incremento marcado de alanina 
transaminases and severe increase of creatinine and BUN (Table 1).

Table 1. Complete blood counts and biochemistry panel results of a woolly monkey with leptospirosis.

\begin{tabular}{llcc}
\hline & Parameter & Result & ISIS value \\
\hline \multirow{2}{*}{ Complete } & RBC & $\downarrow 3.12 \times 10^{\wedge} 6 / \mathrm{uL}$ & $4.19-5.7310^{\wedge} 6 / \mathrm{uL}$ \\
Blood & Hemoglobin & $\star 86 \mathrm{~g} / \mathrm{L}$ & $119-141 \mathrm{~g} / \mathrm{L}$ \\
Counts & WBC & $5.60 \times 10^{\wedge} 9 \mathrm{cells} / \mathrm{L}$ & $7.15-18.25 \times 10^{\wedge} 3 / \mathrm{uL}$ \\
& Neutrophils & 3.4 cells $\times 10^{\wedge} 9 / \mathrm{L}$ & $3.7-13.2 \times 10^{\wedge} 3 / \mathrm{uL}$ \\
& Total Proteins & $\downarrow 5.2 \mathrm{~g} / \mathrm{L}$ & $6.6-7.8 \mathrm{~g} / \mathrm{dL}$ \\
Blood & Albumin & $\star 3.4 \mathrm{~g} / \mathrm{L}$ & $3.9-5.5 \mathrm{~g} / \mathrm{dL}$ \\
Chemistry & ALT/GPT & $\uparrow 131 \mathrm{UI} / \mathrm{L}$ & $34-72 \mathrm{UI} / \mathrm{L}$ \\
Panel & BUN & $\uparrow 192.7 \mathrm{mg} / \mathrm{dL}$ & $11-29 \mathrm{mg} / \mathrm{dL}$ \\
& Creatinine & $\uparrow 5.1 \mathrm{mg} / \mathrm{dL}$ & $0.6-1 \mathrm{mg} / \mathrm{dL}$ \\
& Calcium & $\star 7.7 \mathrm{mg} / \mathrm{dL}$ & $9.4-10.8 \mathrm{mg} / \mathrm{dL}$ \\
\hline
\end{tabular}

On day two, blood was drawn once more to monitor kidney function and as a treatment follow-up. There was a marked increase of creatinine $(813.28 \mu \mathrm{Mol} / \mathrm{L})$, and electrolyte imbalance (plasma sodium $150.1 \mathrm{mMol} / \mathrm{L}$ and phosphate $4.58 \mathrm{mMol} / \mathrm{L}$ ). Urinalysis revealed proteinuria, hematuria, and leukosuria $(100 \mathrm{mg} /$ $\mathrm{dL}$ and 17-20 RBC and 8-10 leucocytes per 40X field, respectively) with low bacteria counts.

The presence of detectable antibodies against Leptospira was confirmed through ELISA IgM test (12 units). According to the manufacturer, results $>11$ units are considered positive for anti-Leptospira IgM. These antibodies are produced during the acute phase of the disease, but may remain detectable for longer periods (2). However, diagnosis was reached considering a positive ELISA result in combination with clinical presentation and epizootiology. Urine dark field microscopy was negative for the presence of spirochetes. Due to unresponsiveness to treatment and clinical deterioration, the monkey was euthanized. In Colombia, euthanasia is performed by qualified veterinarians by administering intravenously 1 $\mathrm{mL}$ of a solution of sodium penthobarbital and sodium difenilhidantoine per $5 \mathrm{~kg}$ total body weight. The first compound acts as a nonselective central nervous system depressant and the latter is an anti-convulsant. This procedure offers a calm, rapid and humane death.

Necropsy revealed presence of abundant abdominal adipose tissue, in addition to free blood in thorax and abdomen. The kidneys (Figure 1) and lungs contained diffuse pinpoint hemorrhages; the latter also had atelectic foci and the trachea was edematous. No gross lesions were found in the spleen, liver, intestines aminotransferasas y un aumento severo de creatinina y BUN (Tabla 1 ).

En el día dos se tomaron muestras adicionales de sangre para monitorear la función renal y como seguimiento al tratamiento. Se presentó un aumento marcado de creatinina $(813.28 \mu \mathrm{Mol} / \mathrm{L})$ y electrólitos (sodio en plasma $150.1 \mathrm{mMol} / \mathrm{L}$ y fosfato en plasma $4.58 \mathrm{mMol} / \mathrm{L})$. El análisis de orina reveló glucosuria, hematuria y proteinuria $(100 \mathrm{mg} / \mathrm{dL}$ y 17-20 RBC y 8-10 leucocitos por campo de 40X, respectivamente) con conteos bajos de bacterias.

Se confirmó la presencia de anticuerpos detectables contra la Leptospira a través de la prueba ELISA IgM (12 unidades). De acuerdo con el fabricante, los resultados > 11 unidades son considerados como positivas para IgM contra Leptospira. Estos anticuerpos son producidos durante la fase aguda de la enfermedad, pero pueden permanecer detectables por períodos más largos de tiempo (2). Sin embargo, se llegó a un diagnóstico considerando un resultado positivo de ELISA en combinación con la presentación clínica y la epizootiología. El análisis de orina en microscopio de campo oscuro mostró un resultado negativo para espiroquetas. El mono fue sacrificado debido a la falta de respuesta al tratamiento y a su deterioro clínico. En Colombia, la eutanasia es realizada por veterinarios calificados mediante la administración intravenosa de 1 $\mathrm{mL}$ de una solución de pentobarbital de sodio y difenilhidantoina de sodio por cada $5 \mathrm{~kg}$ de peso corporal total. El primer compuesto actúa como un depresor no selectivo del sistema nervioso central y el segundo es un anticonvulsivo. Este procedimiento ofrece una muerte tranquila, rápida y humana.

La necropsia reveló presencia de abundante tejido

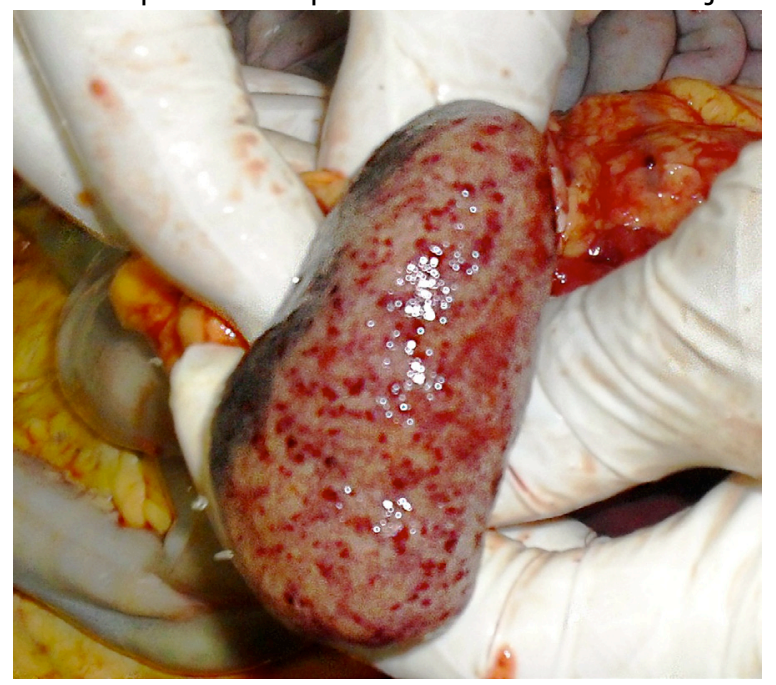

Figure 1. Diffuse petecchiae in the surface of kidneys of an acute case of leptospirosis in a Lagothrix lagothricha in captivity in Cali, Colombia. Photo credit: Zoological Foundation of Cali, 2010. 
and pancreas. The cut surfaces of the kidneys bulged and both kidneys were slightly enlarged. H\&E histopathology revealed multifocal tubuleinterstitial glomerulonephritis, changes in spleen associated with lymphoid depletion, and moderate interstitial pneumonia. The bloody liquid found in thorax and abdomen contained mainly bilirubin, blood cells and proteins.

\section{DISCUSSION}

This clinical case presents the first documented clinical case of leptospirosis in a captive woolly monkey. Very few confirmed cases of leptospirosis have been reported in nonhuman primates in the world (3). The only reported outbreak in Colombia happened in a rehabilitation facility in Cebus capucinus, C. apella and C. albifrons, where most of the primates presented diffuse jaundice and pulmonary hemorrhage (8).

This anicteric infection was characterized by leukocytopenia. The septicemic phase of leptospirosis is associated with damage to vascular lining cells, which combined with the release of bacterial toxins and inflammatory responses to the bacteria (4), account for the pathological features found in this case, including nephritis and petecchiae $(2,8)$. This phase may be followed by a systemic inflammatory response syndrome, which may reflect a leukopenia or leukocytosis, depending on the response of each individual (4), although leukocytosis is more common (2). RBC showed severe poikilocytosis predominantly marked by echinocytes, revealing a toxic disease process with alteration of the RBC membrane. HowellJolly bodies showing signs of hemolytic anemia or an affected spleen; also polycromasia and microcytes, which occur in disseminated intravascular coagulation (DIC). DIC and leukopenia are common findings amongst patients with sepsis, and leptospirosis is considered a frequent cause of sepsis in tropical regions (9). Barbiturate euthanasia solutions can cause vascular damage and necrosis in different organs. However, the incidence of these artifacts is minimal or absent when recommended doses are used (10).

Serum biochemistry analysis revealed hypoproteinemia, hypocalcemia, azotemia and hypoalbuminemia, which are all indicators of a nephropathy, more specifically, acute renal failure. Although jaundice is a common clinical sign associated with leptospirosis, anicteric leptospirosis is also reported as part of the acute febrile syndrome (11). Alanine amino adiposo abdominal, además de sangre libre en el tórax y abdomen. Los pulmones (Figura 1) y riñones presentaban hemorragias puntiformes difusas; este último también tenía focos atelectásicos y una tráquea edematosa. No se encontraron lesiones macroscópicas en el bazo, hígado, intestinos y páncreas. Al corte, la superficie de los riñones sobresalían y ambos riñones estaban aumentados de tamaño. La histopatología reveló glomerulonefritis túbulointersticial multifocal, cambios en el bazo asociado con el agotamiento linfoide y neumonía intersticial moderada. El líquido sangriento encontrado en el tórax y abdomen contenía principalmente bilirrubina, células sanguíneas y proteínas.

\section{DISCUSIÓN}

Este reporte de caso representa el primer caso clínico documentado de leptospirosis en un mono lanudo cautivo. Se han reportado muy pocos casos confirmados de leptospirosis en primates no humanos en el mundo (3). El único brote reportado en Colombia ocurrió en un centro de rehabilitación en Cebus capucinus, C. apella y C. albifrons, donde la mayoría de los primates presentaron ictericia difusa y hemorragia pulmonar (8).

Esta infección anictérica estuvo caracterizada por leucocitopenia. La fase septicémica de la leptospirosis se asocia con daños a las células de revestimiento vascular, que combinado con la liberación de toxinas bacterianas y las respuestas inflamatorias a las bacterias (4), dan cuenta de las características patológicas encontradas en este caso, incluyendo la nefritis y petequias $(2,8)$. Esta fase puede ser anterior a un síndrome de respuesta inflamatoria sistémica, que puede reflejar una leucopenia o leucocitosis dependiendo de la respuesta de cada individuo (4), aunque la leucocitosis es más común (2). Los eritrocitos mostraron poiquilocitosis severa marcada predominante por equinocitos, revelando un proceso de enfermedad tóxica con alteración de la membrana de los eritrocitos. Los cuerpos de HowellJolly mostraron signos de anemia hemolítica o de un bazo afectado, también de policromasia y microcitos, que se presentan durante la coagulación intravascular diseminada (CID). La DIC y leucopenia son resultados comunes entre los pacientes con sepsis y se considera que la leptospirosis es una causa frecuente de sepsis en regiones tropicales (9). Las soluciones barbitúricas pueden causar daño vascular y necrosis en diversos órganos. Sin embargo, la incidencia de estos artefactos es mínima o ausente cuando se utilizan las dosis recomendadas (10).

El análisis bioquímico del suero reveló hipoproteinemia, hipocalcemia, azotemia e hipoalbuminemia, los cuales son indicadores de una nefropatía, más específicamente, de una insuficiencia renal aguda. 
transferase is almost exclusively found in the primate liver; however, increased levels in the absence of jaundice can be the result of a hemolytic crisis, because it is also found in the RBC cytosol. In addition, anicteric disease can occur in peracute processes with severe liver damage and increased enzyme activity (3). The exudate collected from thorax and abdomen was most likely linked to the severe acute multi-organic inflammatory reaction.

The absence of leptospires in the urine viewed by dark-field microscopy may be a reflection of intermittent shedding, known to occur in some species. It could also be due to the bactericidal treatment administered (12).

Very few confirmed cases of leptospirosis have been reported in non-human primates in the world (3). The only reported outbreak in Colombia happened in a rehabilitation facility, where most of the primates presented diffuse jaundice and pulmonary hemorrhage (8). We confirmed leptospirosis with ELISA IgM; these antibodies may remain detectable for several months (3). However, a high IgM titer in a single serum specimen is consistent with a current or recent infection. The specific serovar involved could not be determined due to the known cross-reactivity with in test.

The fact that a single animal was infected in the enclosure might be due to individual infection susceptibility possibly related to endocrine responses (stress) from multiple sources. Behavioral modifications due to captive conditions might also influence this pattern since these folivorous animals have been seen hunting rodents inside the enclosure (unpublished data).

Although leptospirosis is not a reportable disease in Colombia, it is listed internationally as an important occupational disease in captive facilities (6), and it holds economic relevancy. Since leptospirosis diagnosis in non-human primates tends to be characterized by lessevident clinical signs and lesions, and by short-lived antibody responses (3), this clinical case provides evidence that it is important to consider it part of rule-outs or differential diagnosis in future clinical events within and outside of Colombia. Rodent control and biosecurity measures are recommended for all institutions keeping mammals in order to avoid pathogen transmission to personnel and between enclosures.
Aunque la ictericia es un signo clínico común asociado con la leptospirosis, la leptospirosis anictérica también ha sido reportada como parte del síndrome febril agudo (11). La alanina aminotransferasa se encuentra casi exclusivamente en el hígado de los primates; sin embargo, unos niveles más altos en ausencia de ictericia pueden ser el resultado de una crisis hemolítica, porque también se encuentra en el citosol eritrocitario. Además, la enfermedad anictérica puede ocurrir en procesos sobreagudos con daños severos en el hígado y una mayor actividad enzimática (3). El exudado recogido del tórax y abdomen estaba asociado muy probablemente a una reacción inflamatoria multiorgánica aguda severa.

La ausencia de leptospiras en la orina vista por microscopía de campo oscuro puede ser un reflejo de una diseminación intermitente, que se presenta en algunas especies. También podría ser debido al tratamiento bactericida administrado (12).

Se han reportado muy pocos casos confirmados de leptospirosis en primates no humanos en el mundo (3). El único brote reportado en Colombia ocurrió en un centro de rehabilitación, donde la mayoría de los primates presentaba ictericia difusa y hemorragia pulmonar (8). Se ha confirmado la leptospirosis mediante la utilización de la prueba ELISA IgM; estos anticuerpos pueden permanecer detectables durante varios meses (3). Sin embargo, un alto título de IgM en una sola muestra de suero es consistente únicamente con una infección reciente o actual. No se pudo determinar el serovar específico involucrado debido a la reactividad cruzada conocida de la prueba.

El hecho de que un único animal haya sido infectado en el recinto podría ser causado por la susceptibilidad individual a la infección posiblemente relacionada con las respuestas endocrinas (estrés) de múltiples fuentes. Las modificaciones del comportamiento debido a condiciones de cautiverio también podrían influir en este patrón ya que se ha observado que estos animales folívoros cazan roedores dentro del recinto (datos inéditos).

Aunque la leptospirosis no es una enfermedad de declaración obligatoria en Colombia, se muestra internacionalmente como una enfermedad ocupacional importante en instalaciones de cautiverio (6) y tiene una relevancia económica. Puesto que el diagnóstico de la leptospirosis en primates no humanos tiende a estar caracterizado por lesiones y signos clínicos menos evidentes y por las respuestas de anticuerpos de corta duración (3), este caso clínico proporciona evidencia en cuanto a que es importante considerarla como parte de las exclusiones o diagnosis diferenciales en futuros casos clínicos dentro y fuera de Colombia. Se recomienda implementar medidas de bioseguridad y desratización en todas las instituciones que mantienen mamíferos en cautiverio con el fin de evitar 


\section{Acknowledgements}

We thank Dr. Carlos Lopez DVM for his advice on clinical pathology, Dr. Sonia M. Hernandez DVM PhD for her comments, Leonor Oviedo for laboratory assistance and the staff at the Colombian Agricultural Institute (ICA) for sample provision, and to the personnel at the Zoological Foundation of Cali who were actively involved in this case.

Conflict of interests: Authors declare having no conflict of interest. la transmisión de patógenos al personal y entre los recintos.

\section{Agradecimientos}

Agradecemos al Dr. Carlos López DVM por su consejo en patología clínica, a la Dr. Sonia M. Hernández DVM PhD por sus comentarios, a Leonor Oviedo por su asistencia en el laboratorio y al personal del Instituto Colombiano Agropecuario (ICA) por la disposición de las muestras, y al personal de la Fundación Zoológica de Cali que participaron activamente en este caso.

Conflictos de interés: Los autores declaran no tener ningún conflicto de interés.

\section{REFERENCES}

1. Astudillo-Hernández M, González-Rodríguez A, Batista-Santiesteban N, Mirabal-Sosa M, Menéndez-Hernández J. Estudio seroepidemiológico de la leptospirosis humana en el departamento del Valle del Cauca, Colombia. Rev Cub Med Trop 2009; 61:152-159.

2. Adler B, de la Pena-Moctezuma A. Leptospira and leptospirosis. Vet Microbiol 2010; 140:287-296.

3. Ubb KVF, Kennedy PC, Palmer N. Pathology of Domestic Animals. San Diego: Academic Press; 2007. Pg: 503-510.

4. Minette HP. Leptospirosis in primates other than man. Am J Trop Med Hyg 1966; 15:190-198.

5. Thayaparan S, Robertson I, Amraan F, Su'ut $L$, Abdullah MT. Serological prevalence of Leptospiral infection in wildlife in Sarawak, Malaysia. Borneo J Res Sci Tech 2013; 2:7982.

6. Forsyth MB, Morris AJ, Sinclair DA, Pritchard CP. Investigation of zoonotic infections among Auckland Zoo staff: 1991-2010. Zoonoses Public Health 2012; 59:561-567.

7. González-Astudillo V, Wehdeking-Hernández $\mathrm{D}$, Peña-Stadlin JE, Arias-Bernal L, LomboRodriguez DA, Astudillo-Hernandez M. Comparative seroprevalence of Leptospira interrogans in Colombian mammals along a climatic gradient. J Zoo Wildl Med 2012; 3:768-775.
8. Szonyi B, Agudelo-Florez P, Ramírez M, Moreno N, KoAI. An outbreak of severe leptospirosis in capuchin (Cebus) monkeys. Vet J 2010; 188: 237-239.

9. Chierakul W, Tientadakul $P$, Suputtamongkol Y, Wuthiekanun V, Phimda K, Limpaiboon R, et al. Activation of the coagulation cascade in patients with leptospirosis. Clin Infect Dis $2008 ; 46: 254-260$.

10. Grieves JL, Dick EJ Jr, Schlabritz-Loutsevich NE, Butler SD, Leland MM, Price SE, et al. Barbiturate euthanasia solution-induced tissue artifact in nonhuman primates. J Med Primatol 2008; 37:154-161.

11. Assimakopoulos SF, Fligou F, Marangos M, Psilopanagioti A, Filos KS. Anicteric leptospirosis-associated severe pulmonary hemorrhagic syndrome: a case series study. Am J Med Sci 2012; 344:326-329.

12. Cortese VS, Behan S, Galvin JE, Penka DR, Ramsey D, Bryson WL, et al. Evaluation of two antimicrobial therapies in the treatment of Leptospira borgpetersenii serovar hardjo infection in experimentally infected cattle. Vet Ther 2007; 8:201-208. 